\title{
ANALYSIS OF THE INFLUENCE OF INSTITUTIONAL QUALITY, CAPITAL ABILITY, EDUCATION, TRAINING QUALITY AND ENTREPRENEURIAL MINDSET ON THE SUCCESS OF KUBE PROGRAM IN SEWON, BANTUL, YOGYAKARTA
}

\author{
Hartati Anis Siti, Kussujaniatuni Sri* \\ Faculty of Economics, University of National Development "Veteran" Yogyakarta, \\ Yogyakarta, Indonesia \\ *E-mail: sri.kussujaniatun@upnyk.ac.id
}

\begin{abstract}
The research problem is related to the ways on how to reach the success of KUBE program, in which Sewon serves as the village that gets the highest grant from the local government in Bantul. The research objective is to identify several factors that influence the success of the program in running the businesses and in their innovation. The research method applies survey, interview to the coordinator of KUBE, and questionnaires. The analysis model used is multiple regression. The research result shows that the institutional variables, capital ability, education and training quality and entrepreneurial mindset influence the success of the program. Entrepreneurial mindset is a dominant variable that influences the success of the program. The implementation of the research result is that there is a need to empower the society through training and assistance in KUBE, especially entrepreneurship training, in which in the future it can improve the income and the independence of $\mathrm{PKH}$ that serves as the success of KUBE program.
\end{abstract}

\section{KEY WORDS}

Institution, capital ability, education, training quality, program success.

To achieve its goal to improve the quality of social welfare management, Social Ministry of Republic of Indonesia forms a social program called KUBE (Joint Business Group). KUBE is a group business, stipulated by Directorate General of the Social Empowerment and Poverty Alleviation aims at empowering poor community groups by providing business capital through the program of Social Empowerment Direct Support to manage their productive economic business.

Poverty in country side or in the city with dense population areas becomes an urgent problem that needs a serious solution, especially in Bantul regency where there are still social imbalance and complex social problem that becomes some problems that need to be solved immediately. Poverty problem is a problem that needs to be handled in cross sectional, continuous, and synergized. This is because poverty is a problem that becomes the source of other social problems such as abandoned kids, beggars, homeless, indecent living houses, social disorder, and so on (Priadana, 2010). Supported by Irobi, 2008 in Idris 2015 that throughout the world, poor people are excluded from formal financial system. This exclusion ranges from partial exclusion in developed countries to full or near full exclusion in less developed countries. This makes poverty an important development challenge and explains why poverty became an issue of concern both at the local and international levels.

Timbulharjo village in Sewon is a beneficiary that gets the highest grant from the local government because Sewon is a transitional district with the highest level of poor residents. The KUBE program is addressed to the poor society, but KUBE program does not merely emphasize on economic aspect, but emphasize more on the capacity development with the aim to penetrate the entrepreneurship values and the social relation of the Social Assisted Families. This program is given to 10 households optimally with the grant of RP. 20.000.0000 which is given once in their life for each group. The members of KUBE consist of $70 \% \mathrm{PKH}$ (Family Hope Program) and 30\% from the people listed in BDT (Integrated Database). 
The goal to be reached in KUBE program is to improve the success of the business of KUBE members in groups, increase the income of the society, develop the business of the society, and improve the social care and solidarity among the members of KUBE and the surrounding society. However, the phenomena in the real practice is that not all of the residents know the access of KUBE and the existing KUBE still needs development, assistance, and supervision. Therefore, the interest of the research is to analyze how the impact of the success of the grant and KUBE program, in which Timbulharjo is the beneficiary with the highest grant from the local government of Bantul.

\section{LITERATURE REVIEW}

According to Social Ministry of Republic of Indonesia Number 25 Year 2015 about Joint Business Group, Joint Business Group, called KUBE, is a business group formed for the poor that grows and develops with their effort and their work in conducting their productive economic business to increase their family income.

KUBE aims at empowering the poor, developing the basic social service, and increasing income, individual capacity, and business ability of their members so that they can fulfill their needs independently, as well as improving social solidarity.

The criteria of the establishment of KUBE are as follows:

- Having potential, willingness, and ability to develop joint business;

- Having similar business type and living within the same village/district;

- Having access constraints to market, capital, and business.

There are at least 5 (five) households and 15 (fifteen) households at the most for the members of KUBE. The structure of the organization of KUBE consists of head, secretary, treasurer, and members. The organization of KUBE is selected based on the result of discussion/decision of the whole members of the group.

According to Tri Wahyu Rejekiningsih (2004), small industry involves all companies or businesses, in which in their practice, the businesses change raw material into semi-finished products or from products with less value into products with higher value.

Related to small industry, there are several special characteristics of small industry stated by Sutojo, et al. (1994) in Baswir (1998), as follows:

- More than half of the small industries are established as part of development of the smaller industries;

- Besides capital problem, other problems faced by small industries vary based on the level of the business development;

- Most of the small industries are not able to fulfill the administration requirements to get bank loan;

- Almost $60 \%$ of the small industries still use traditional technology.

- Almost half of the small industries only use less than $60 \%$ of the capacity installed.

- The market share of the small industries decreases due to the lack of capital, poor technology, and poor management.

- Almost $70 \%$ of the small industries conduct direct marketing to the consumers.

The prior research conducted by Priadana (2010) uses the variables of regulation and organization system, KUBE institutional quality, economic capital ability of the members, education and training, entrepreneurial mindset, and partnership strategy as the variables in developing KUBE. The variables in developing KUBE have influence on the improvement of the members of KUBE, and the variable of the income increase of the KUBE members also gives influence to the poverty alleviation. Timbulharjo village in Sewon is one of the strategic places to develop small industries. Research result by Kussujaniatun and Kismantoroaji (2017) shows that the society is expected to know and realize that in their region there are many potentials especially in utilizing the potentials, and thus there is a need to review about the social and economic improvement aspects.

Small and mid industries play significant role in economic development and growth. In general, business units in small enterprises open more job vacancies, as a support in 
realizing better income for families. Business units in small enterprises tend to take more workers. This can be seen that around $99 \%$ of the business units in Indonesia are in small and mid scales and it is noted that it can create job vacancies for more than 99,4 million workers. Meanwhile, big business take around 2,8 million workers (data from Cooperatives and Small and Medium Enterprises Ministry year 2010). Therefore, this employment helps Indonesia to improve the welfare of the society and to help the society to survive to face the crisis. It can be stated that business units in small enterprises have great role and contribution to the economic of Indonesia, and the real contribution is by providing employment. Society empowerment is needed to improve the economic of the society. Empowerment is an effort to build the society's ability by encouraging, motivating, and improving the awareness of the potentials that they have and trying to develop potentials to become real actions (Zubaidi, 2013).

Society empowerment level can be realized by doing active participation from the society that is facilitated by having the actors of the empowerment. The main target of the society empowerment is those who are weak and with no power or ability to access productive resources or society that are left behind in the development. The final goal of the society empowerment process is to make the society independent so that they can improve their living and optimize the resources that they have (Kesi Widjajanti, 2011).

Besides, according to Kussujaniatun and Kismantoroaji (2017), social interaction has crucial influence in society empowerment. This result is based on the great cooperation between the craftsmen and the local government that needs to be maintained, the interaction with the partners in producing the goods, interaction with the supplier in raw material availability, interaction with the broker/agent in marketing, and interaction with the banking partner in capital supply.

Based on the Regional Regulation of Bantul Regency Number 6 Year 2013 Article 16 letter $\mathrm{B}$, the efforts in empowering the society to alleviate the poverty are as follows: skill training in numerous activities and the levels of the training; assistance in business management; facilities in improving society's participation and self-support; facilities in organizing volunteers/observers in poverty alleviation; facilities in managing joint business; facilities in partnership between the public the private institutions.

The research problem is whether the variables of institutional, capital ability, education and training quality, and entrepreneurial mindset influence the success of KUBE program in Sewon, Bantul.

\section{METHODS OF RESEARCH}

The design of the research is descriptive and inductive that is expected to explain the model of the success of the program by trying to review the influence of the variables, which are institutional aspects of KUBE, economic capital ability of KUBE members, ability of the education and training of KUBE members, entrepreneurial mindset, in improving the income and the independence of KUBE members. After conducting pre-survey by identifying the characteristics of KUBE, it shows that the grant from the Social Department for KUBE is of $\mathrm{Rp}, 20.000 .000$ for each KUBE. There are $12 \mathrm{KUBEs}$, and in each KUBE there are 10 members. The members of KUBE are $70 \%$ taken from PKH (Family Hope Program) and $30 \%$ from the people listed in BDT (Integrated Database). The sample of the research is the members of KUBE who are actively participate. There are 70 members spread in the village of Sewon, Bantul. The data used is primary data, gathered by suing survey method through the use of questionnaires. The analysis technique in this research is multiple regression.

Based on the design of the research, there are several variables that will be researched, such as:

- Free Variables. Free variables consist of the institutional quality of KUBE, members' entrepreneurial mindset, the education and training ability of the members, and the ability of the economic capital of the members;

- Bound Variable. The bound variable is the success of the KUBE program. 


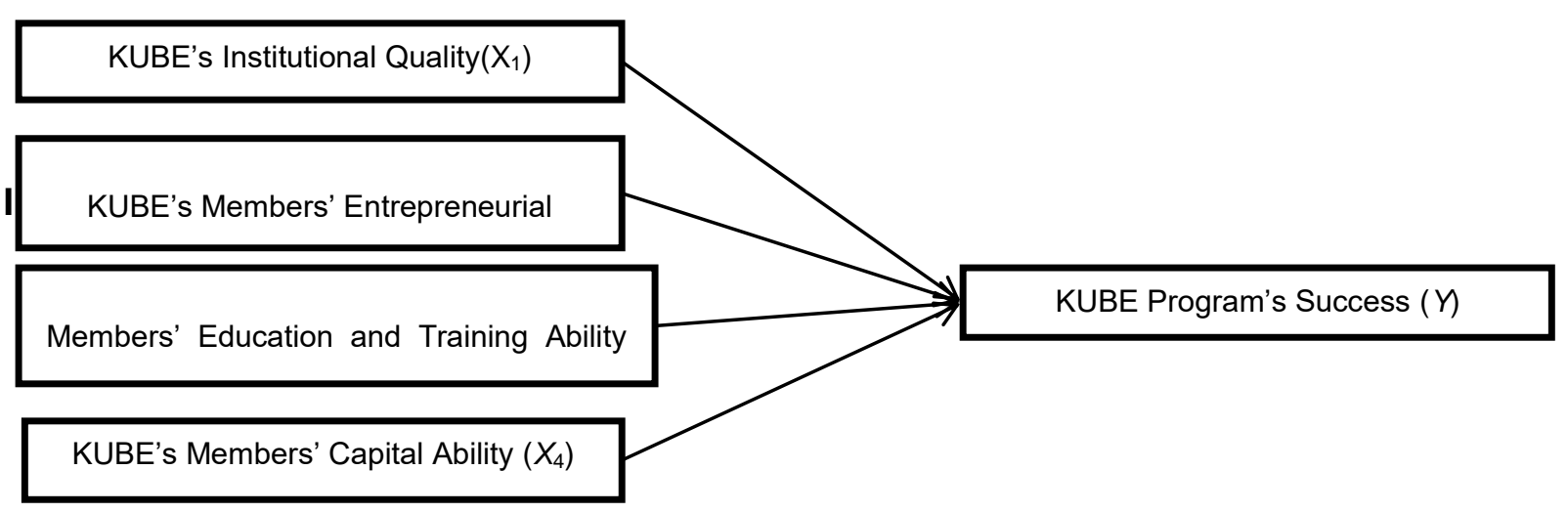

Figure 1 - Research Variables

The variable of the institutional quality has several sub-variables that have indicators in each sub-variable, as follows:

Sub Variable: Planning. Indicators: planning, participation of all parties in making the plans, the socialization of the planning;

Sub Variable: Organization. Indicators: organization structure; human resources quality, organization ease;

Sub Variable: Implementation. Indicators: the availability of the supports, sufficient budgeting, implementation effectiveness;

Sub Variable: Supervision. Indicators: supervision ease, supervision continuity.

The variable of members' economic capital ability has several sub-variables which have indicators, as follows:

Sub-Variable: Grant from KUBE executors. Indicator: cash grant; machine and work tools; raw material support;

Sub-Variable: additional capital from others. Indicator: bank loan; non-bank loan; tools and raw material support.

The variable of education and training ability has several sub-variables which have indicators, as follows:

Sub-Variable: Educators and Trainers. Indicator: the availability of educators and trainers; the quality of educators and trainers;

Sub-Variable: Facilities and Infrastructures. Indicators: the availability of facilities and infrastructure; the quality of facilities and infrastructures; the utilization of facilities and infrastructures;

Sub-Variable: Motivation and Service. Indicator: participants' motivation; service to the participants; the attitude of the leaders and staffs;

Sub-Variable: Technology Mastery. Indicator: the availability of applied technology; easy access and the use of technology.

The variable of entrepreneurial mindset has several sub-variables which have indicators in each sub-variable, as follows:

Sub-Variable: Perception towards planning and competitors. Indicator: understanding about planning and competition; willingness to compete;

Sub-Variable: Perception towards innovation. Indicator: willingness to develop oneself; willingness to be different from others;

Sub-Variables: Perception towards proactive action. Indicator: willingness to seek information; ability to act fast;

Sub-Variables: Perception towards risk. Indicator: understanding risks; dare to take risks from the actions; always learning from experience and failure. follows:

The variable of KUBE program has several sub-variables which have indicators, as

Sub Variable: Production and Business Improvement. Indicator: production number, production quality, production type addition; 
Sub-Variable: operational ability improvement. Indicator: managerial capability; technique improvement; team work; employees' productivity improvement;

Sub-Variable: cooperation and market access improvement. Indicator: cooperation improvement; marketing area improvement; consumers' confidence improvement.

\section{RESULTS AND DISCUSSION}

The analysis technique used is multiple regression analysis: $X_{1}=$ KUBE's institutional quality; $X_{2}=$ KUBE members' entrepreneurial mindset; $X_{3}=$ KUBE members' education and training ability; $X_{4}=$ KUBE members' economic capital ability; $Y=$ The Success of KUBE Program.

Table 1 - Research Model

\begin{tabular}{|c|c|c|c|c|c|}
\hline \multirow[b]{2}{*}{ M Model } & \multicolumn{2}{|c|}{ Unstandardized Coefficients } & \multirow{2}{*}{$\frac{\text { Standardized Coefficients }}{\text { Beta }}$} & \multirow[b]{2}{*}{$t$} & \multirow[b]{2}{*}{ Sig. } \\
\hline & $\mathrm{B}$ & Std. Error & & & \\
\hline 1 (Constant) & 32.928 & 2.576 & & 12.783 & .000 \\
\hline$\underline{X 1}$ & -.227 & .143 & -.136 & -1.589 & .117 \\
\hline $\mathrm{x} 2$ & .591 & .211 & .378 & 2.804 & .007 \\
\hline$\underline{\mathrm{X} 3}$ & -.109 & .031 & -.289 & -3.481 & .001 \\
\hline $\mathrm{X} 4$ & .479 & .204 & .331 & 2.351 & .022 \\
\hline
\end{tabular}

a. Dependent Variable: $Y$.

The equation can be stated as follows: $Y=-0,227 \mathrm{X} 1+0.591 \mathrm{X} 2-0.109 \mathrm{X} 3+0.479 \mathrm{X} 4$ $+\varepsilon 1$. Furthermore, based on the result of statistical tests, it shows that there is a significant influence of each free variable $(X)$ on the bound variable $(Y)$ with the first details as follows: Entrepreneurial mindset (X2), Quality of education and training (X3), Capital Ability of members (X4) influence significantly to the success of the program (Y). Meanwhile, the second details show that the variable of institutional quality of KUBE (X1) does not influence significantly to the success of the program $(Y)$. The value of the regression coefficient of the variable of institutional quality $(X 1)$ is $-0,227$ meaning that the higher institutional quality is, the less influence it will give to the success of the program. Similarly, the value of the variable of education and training quality is $-0,109$ meaning that the higher ability of the education and training is, the less influence it will give to the success of the program. The coefficient of the capital ability variable is 0,479 meaning that the higher capital ability of the members is, the higher chance it will get to the success of the program. The highest coefficient is on the variable of entrepreneurial mindset of the members of 0,591 meaning that the greater entrepreneurial mindset is, the higher influence it will give to the success of the program. Therefore, the variable of entrepreneurial mindset is the dominant variable that influences the success of KUBE program.

\section{CONCLUSION}

Research result shows that entrepreneurial mindset, education and training quality and capital ability have significant influence on the success of the program. Meanwhile, the variable of institutional quality does not have significant influence on the success of the program. Thus, entrepreneurial mindset is the most dominant variable that influences the success of the KUBE program in Timbulharjo, Sewon, Bantul. Based on those results, the implementation of the research result is that there is a need to conduct a community empowerment through training and assistance of KUBE, especially entrepreneurship training to improve the entrepreneurial mindset, in which in the near future it can improve the income and the independence of PKH as the success of the KUBE program. 


\section{REFERENCES}

1. Baswir, Revrisond. 1998. Akuntansi Pemerintah Indonesia (Indonesia Government Accountancy). Edisi 3. Yogyakarta: BPFE.

2. Idris, Adama J. 2015. Micro-Credit as a Strategy for Poverty Alleviation among Women Entreprneurs in Nasarawa State, Nigeria. Journal of Business Studies Ouarterly. 6(3), 122-144.

3. Irobi, N.C. 2008. Microfinance and Poverty Alleviation: A Case Study of Obazu Progressive Women Association Mbieri, Imo State, Nigeria (Unpublished master's thesis). Sverigeslantbruks Universitet, Uppsala, Sweden.

4. Kementerian Koperasi dan Usaha Kecil Menengah Tahun 2010.

5. Kussujaniatun,Sri.,Kismantoroadji. 2017. Pengaruh Peningkatan Sosial dan Ekonomi terhadap Perilaku Kewirausahaan (The Influence of Social and Economic Improvement on Entrepreneurial Attitude). International Conference on Technology Enginneering and Social Science, HASE, Nabu Research Academy.

6. Kussujaniatun, Sri, dan Kismantoroaji,Teguh. 2017. Community Empowerment In Teak Root Potential Area.7th International Conference on Biotechnology and Environmindset Management (ICBEM 2017).

7. Peraturan Daerah Kabupaten Bantul Nomor 06 Tahun 2013 tentang Penanggulangan Kemiskinan (Poverty Alleviation)

8. Peraturan Menteri Sosial RI Nomor 25 tahun 2015 tentang Kelompok Usaha Bersama, Kelompok Usaha Bersama (Joint Business Group)

9. Priadana, Moh. Sidik. 2010. Analisis Faktor Penentu Keberhasilan serta Dampak dari Kelompok Usaha Bersama di Jawa Barat (Analysis on the Factors Determining the Success and the Impacts of Joint Business Group in West Java). Trikonomika vol 9 no 2, 78-86, 2010, ISSN 1411-514X

10. Rejekiningsih, Tri Wahyu. 2004. Dinamika Pembangunan (Development Dynamics) . Universitas Diponegoro Semarang. Vol. 1 No. 2 Desember 2004, hal. 125-136.

11. Widjajanti, Kesi. 2011. Model Pemberdayaan Masyarakat (Society Empowerment Model). Semarang. Jurnal Ekonomi Pembanguna. Volume 12, Nomor 1, Juni 2011, hlm.15-27.

12. Zubaidi. 2013. Pengembangan Mayarakat: Wacana dan Praktik [Developing Community: Discourse and Practice]. Jakarta: Kencana. 